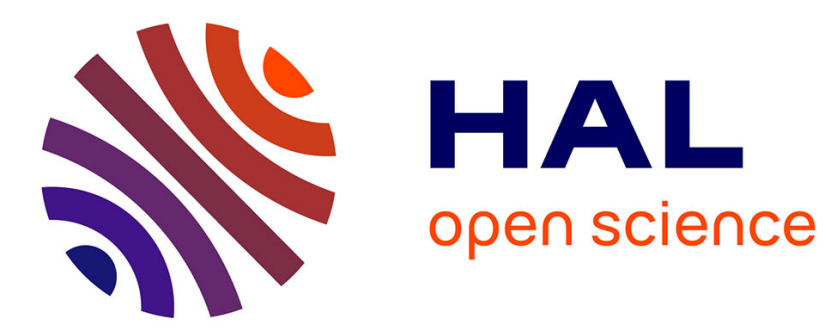

\title{
DEVELOPMENTS IN SOLID SOLUTION ELECTRODES
}

\author{
B. Steele
}

\section{To cite this version:}

B. Steele. DEVELOPMENTS IN SOLID SOLUTION ELECTRODES. Journal de Physique Colloques, 1978, 39 (C2), pp.C2-198-C2-203. 10.1051/jphyscol:1978234 • jpa-00217389

\section{HAL Id: jpa-00217389 https://hal.science/jpa-00217389}

Submitted on 1 Jan 1978

HAL is a multi-disciplinary open access archive for the deposit and dissemination of scientific research documents, whether they are published or not. The documents may come from teaching and research institutions in France or abroad, or from public or private research centers.
L'archive ouverte pluridisciplinaire HAL, est destinée au dépôt et à la diffusion de documents scientifiques de niveau recherche, publiés ou non, émanant des établissements d'enseignement et de recherche français ou étrangers, des laboratoires publics ou privés. 


\title{
DEVELOPMENTS IN SOLID SOLUTION ELECTRODES
}

\author{
B. C. H. STEELE \\ Department of Metallurgy and Materials Science, \\ Imperial College, London, S.W.7, England
}

\begin{abstract}
Résumé. - Le concept d'une électrode à solution solide est brièvement décrit et nous attirons l'attention sur le fait que l'on manque d'un modèle théorique avec lequel on peut prédire les propriétés thermodynamiques de ces matériaux non stœchiométriques très défectueux. On récapitule les propriétés des anodes et des cathodes à solutions solides actuelles avec des commentaires sur les changements de volume qui arrivent en incorporant $\mathrm{du} \mathrm{H}^{+}, \mathrm{Ag}^{+}, \mathrm{Cu}^{+}, \mathrm{Li}^{+}$; le degré de la réversibilité, et l'influence de non-stœchiométrie de la maille de l'hôte. On accentue ces propriétés particulières par l'inclusion et la discussion des mesures récentes sur $\mathrm{Li}_{x} \mathrm{VO}_{2}, \mathrm{Cu}_{x} \mathrm{FeS}_{4}, \mathrm{~K}_{1+x} \mathrm{Fe}_{11} \mathrm{O}_{17}$. Enfin, on fait des commentaires sur les propriétés des interfaces des électrodes à solutions solides.
\end{abstract}

\begin{abstract}
The concept of a solid solution electrode is briefly reviewed, and attention is drawn to the lack of an appropriate theoretical model which could be used to predict the thermodynamic properties of these grossly defective non-stoichiometric materials. The properties of existing solid solution anodes and cathodes are summarized with comments about the volume changes accompanying the incorporation of $\mathrm{H}^{+}, \mathrm{Ag}^{+}, \mathrm{Cu}^{+}, \mathrm{Li}^{+}$; the degree of reversibility, and the influence of the non-stoichiometry of the host lattice. These particular properties are emphasized by the inclusion and discussion of recent measurements on $\mathrm{Li}_{x} \mathrm{VO}_{2}, \mathrm{Cu}_{x} \mathrm{FeS}_{4}$, and $\mathrm{K}_{1+x} \mathrm{Fe}_{11} \mathrm{O}_{17}$. Finally some comments are made about the interfacial properties of solid solution electrodes.
\end{abstract}

1. Introduction. - The concept of solid solution electrodes (S.S.E.) has been summarized by Steele [1] in the diagram reproduced in figure 1 . The area between the two curves represents the theoretical partial molar free energy available for the electrochemical storage system which can be represented schematically by cells of the type,

$\begin{array}{ccc}\mathrm{A} x \mathrm{M}^{\prime} \mathbf{X}^{\prime} & \text { Electrolyte Phase } & \mathrm{A} y \mathrm{MX} \\ \text { (Anode) } & \mathrm{A}^{+} & \text {(Cathode) }\end{array}$

where $\mathrm{A} x \mathrm{M}^{\prime} \mathrm{X}^{\prime}$ and $\mathrm{A} y \mathrm{MX}$ are the grossly defective non-stoichiometric anode and cathode phases respec-

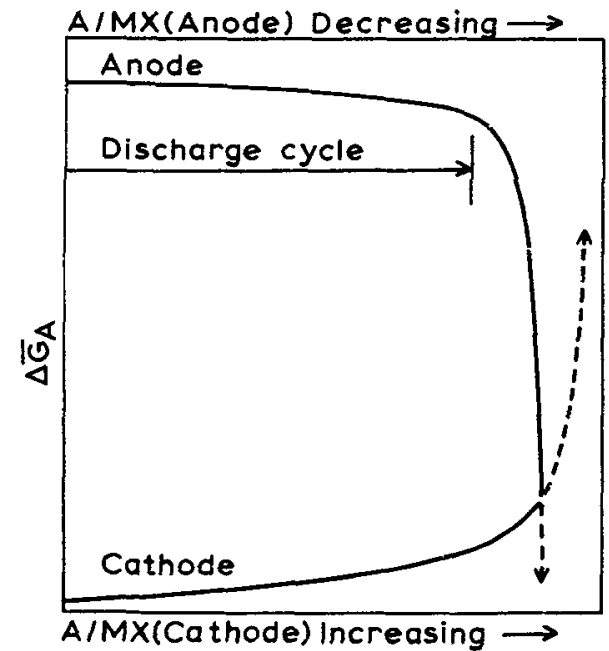

FIG. 1. - Schematic diagram depicting operation of a battery incorporating two solid solution electrodes. tively. During discharge the electroactive species A is transferred from the anode to the cathode and the corresponding cell voltage is given by the relationship

$$
E=\frac{\overline{\bar{G}}_{\mathrm{A}} \text { (cathode) }-\bar{G}_{\mathrm{A}} \text { (anode) }}{n F} .
$$

Many systems [2, 3] are now known to possess useful specific theoretical energy densities as indicated in table I. In operation the S.S.E. materials must also be able to sustain satisfactory current densities and chemical diffusion coefficients around $10^{-6} \mathrm{~cm}^{2} / \mathrm{s}$ are therefore desirable. As the self $\left(D_{i}^{*}\right)$ and chemical

\section{TABLE I}

Approximate theoretical energy densities for selected lithium battery systems $\left(^{*}\right)$

$\begin{array}{ccc}\text { Couple } & \mathrm{Wh} / \mathrm{kg} & \mathrm{Wh} / \mathrm{cm}^{3} \\ - & - & - \\ \mathrm{Li} / \mathrm{TiS}_{2} & 450-480 & 1.1 \\ \mathrm{Li} / \mathrm{TiS}_{3} & 970 & 0.9 \\ \mathrm{Li} / \mathrm{NbS}_{3} & 670 & 1.9 \\ \mathrm{Li} / \mathrm{NbSe}_{3} & 440 & 1.6 \\ \mathrm{Li} / \mathrm{NbSe}_{4} & 450,550 & 1.4,1.5 \\ & & (4 \text { and } 5 \mathrm{Li}) \\ \mathrm{Li} / \mathrm{SOCl}_{2} & 2045 & 2.3 \\ \mathrm{Na} / \mathrm{S} \text { (single phase) } & 310 & \end{array}$

(*) Calculated on basis of anode and cathode materials only, ignoring electrolyte, separators, and containers. 
$\left(\widetilde{D}_{i}\right)$ diffusion coefficients can be combined in expressions of the type,

$$
\tilde{D}_{i}=D_{i}^{*} \frac{\mathrm{d} \ln a_{i}}{\mathrm{~d} \ln X_{i}}
$$

if follows that the self-diffusion coefficient should also have values approaching $10^{-6} \mathrm{~cm}^{2} / \mathrm{s}$ as the thermodynamic term ideally will have a value around in between 1 and 10 to optimize the domain of useful available free energy in figure 1 . The influence of the thermodynamic factor is demonstrated in figure 2 for hydrogen in niobium. Clearly then S.S.E. materials can be classified as superionic conductors.

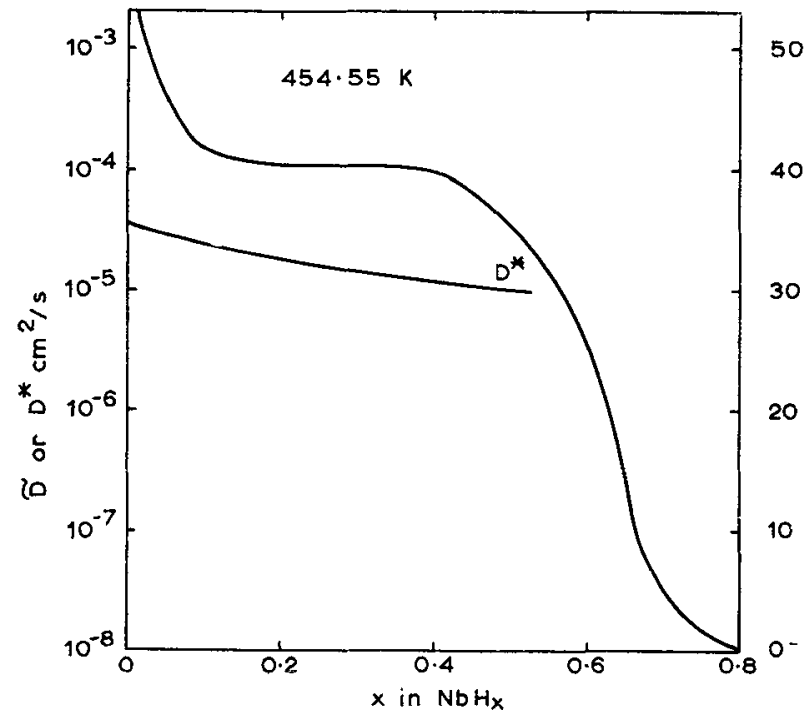

FIG. 2. - Self $\left(D^{*}\right)$ and chemical diffusion coefficients $(\tilde{D})$ of hydrogen in $\mathrm{NbH}_{x}$. Partial molar free energy values also included.

2. Thermodynamic behaviour of solid solution electrodes. - The $\bar{G}_{\mathrm{A}}$ composition curves (Fig. 1) should be as flat as possible to optimize the available free energy and this requirement demands very non-ideal thermodynamic behaviour. Most of the simple theories for concentrated solutions use the Bragg-Williams (regular solution) approach with a constant interaction energy but obviously (see Fig. 3) these models are inadequate to describe the experimental results of, for example, the $\mathrm{Li}^{-\mathrm{TiS}_{2}}$ system [4]. More sophisticated models are required and the statistical approach [5] used for grossly defective fluorite solid solutions might be a useful starting point.

Another parameter which is difficult to predict at present is the maximum solubility of the incorporated species. For simple binary alloy systems the semiempirical approach suggested by [6] is useful, and figure 4 contains some relevant data for solubility of $\mathrm{Li}$ in metallic systems which might be used as solid solution anodes.

3. Summary of solid solution behaviour. - Available information on S.S.E. systems has already been

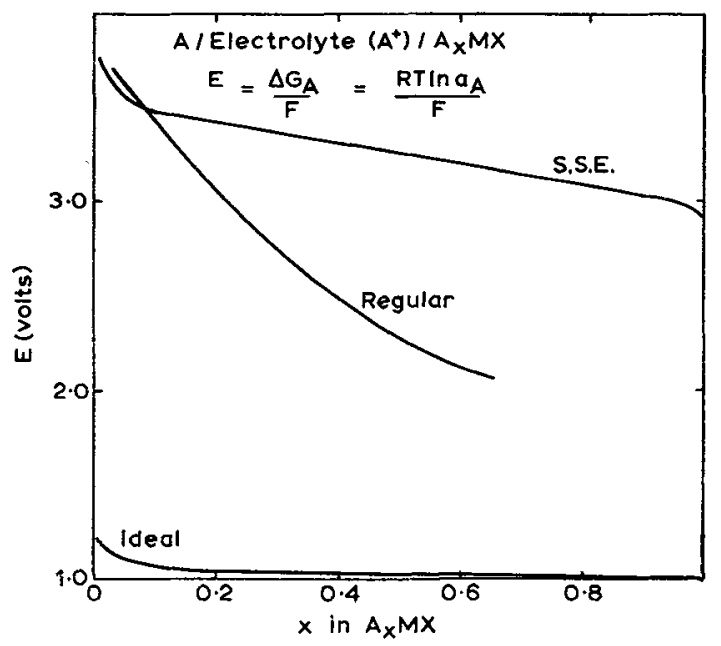

FIG. 3. - Voltage composition curves for ideal, regular and typical $\left(\mathrm{Li}_{-} \mathrm{TiS}_{2}\right)$ solid solution electrodes.

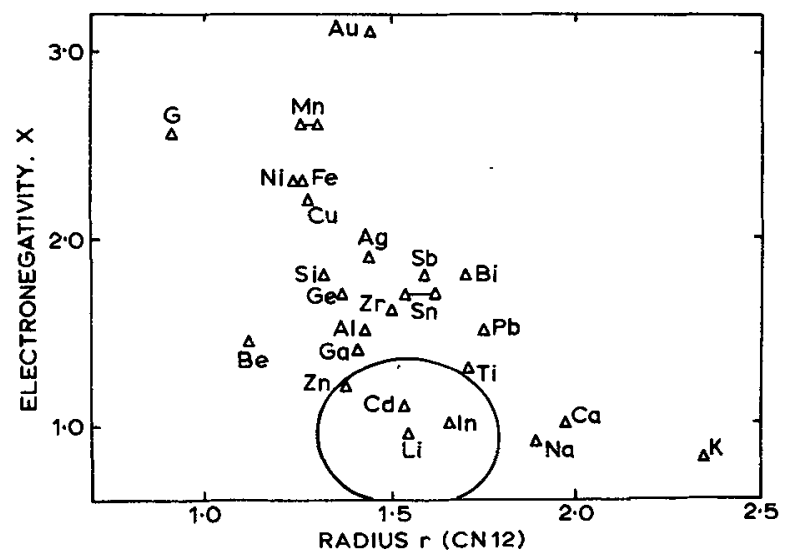

Fig. 4. - Plot of electro-negativity versus size. For signuficant ( 5 atom $\%$ ) mutual solubility typical size deriation is $15 \%$ and electro-negativity difference is 0.4 .

reviewed $[2,7,8]$ and a list of relevant S.S.E. materials are summarized in table II with appropriate comments. Special mention should be made of the system $\mathrm{Li}^{-\mathrm{TiS}_{2}}$ as this couple satisfies many of the requirements for a practical solid solution electrode. The theoretical specific energy density has a satisfactory value of $470 \mathrm{Wh} / \mathrm{kg}$ (Table I) and moreover the cell is completely reversible in contrast to other solid solution materials such as $\mathrm{TiS}_{3}, \mathrm{NbSe}_{4}$, etc... The emf composition curve is relatively shallow (Fig. 3) and so it is not surprising that prototype batteries have already been constructed $[9,10,11]$. The current densities available from these batteries provides further evidence for the rapid transport of lithium ions within the $\mathrm{TiS}_{2}$ electrodes and confirm the chemical diffusion values reported for single crystals of $\mathrm{TiS}_{2}$ [4]. It may be concluded therefore that $\mathrm{TiS}_{2}$ is an excellent solid solution electrode for lithium when used in conjuction with a liquid electrolyte such as an aprotic solvent (e.g. propylene carbonate) or molten salt (e.g. LiCl- 
TABLE II

Summary of solid solution electrode behaviour

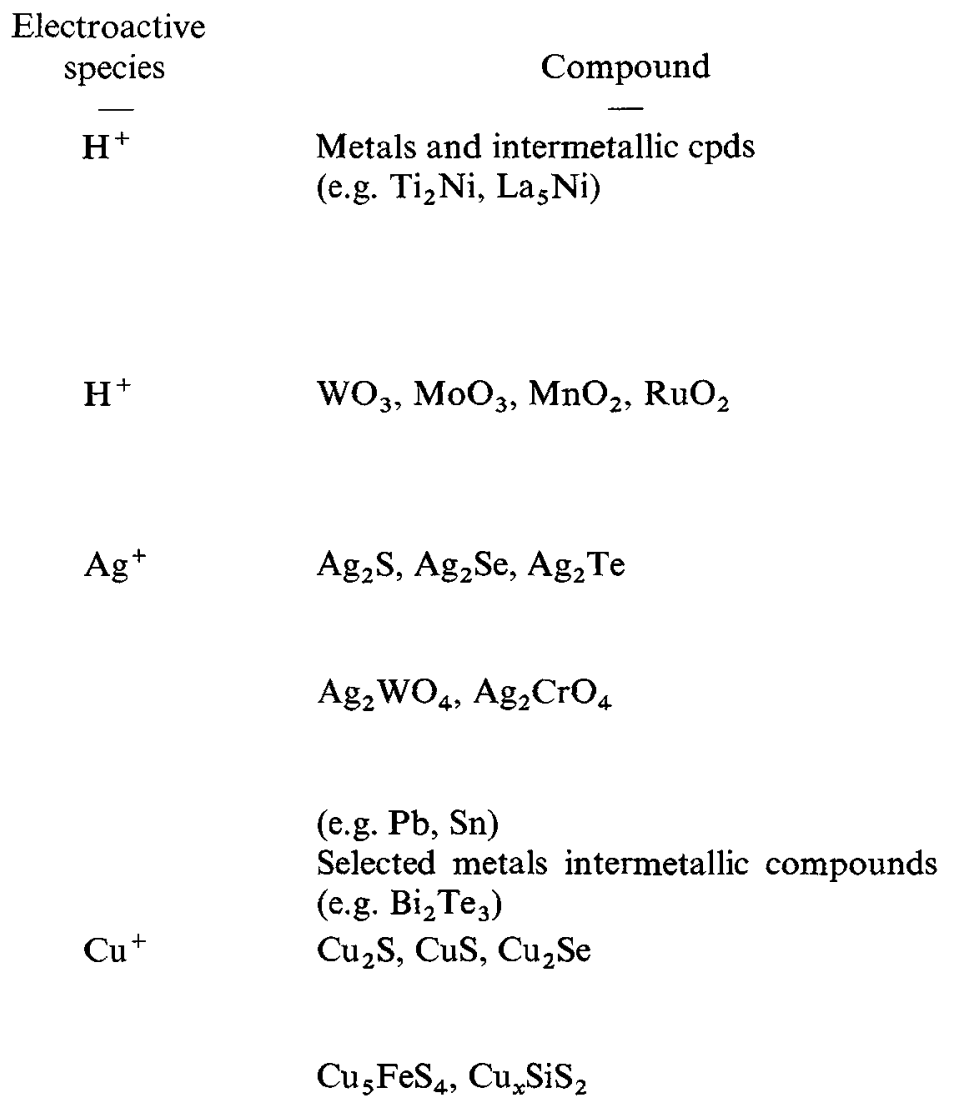

Selected metals and semi-conductors

$\mathrm{V}_{2} \mathrm{O}_{5} \mathrm{MoO}_{3}$

$\mathrm{Li} \quad \mathrm{TiS}_{2}, \mathrm{TiS}_{3}^{*}, \mathrm{NbSe}_{2}$, $\mathrm{NbSe}_{3}^{*} \mathrm{NbSe}_{4}^{*}(\mathrm{SN})_{x}^{*}$

$\mathrm{ZrS}_{2}$

\begin{abstract}
Comments
Large diffusion coefficients

$\left(\sim 10^{-6} \mathrm{~cm}^{2} / \mathrm{s}\right)$.

Large ranges of composition possible.

Volume changes associated with incorporation of hydrogen usually necessitate use of powders.

Incorporation of hydrogen function of stoichiometry due to presence of shear planes. Transport data confusing $\left(10^{-6}-10^{-16} \mathrm{~cm}^{2} / \mathrm{s}\right)$.

Large diffusion coefficients at elevated temperatures $\left(\sim 150^{\circ} \mathrm{C}\right)$. Relatively small deviations from stoichiometry.

Small diffusion coefficients. One dimension channels blocked by crystallographic faults.

Large diffusion coefficients

(e.g. $10^{-6} \mathrm{~cm}^{2} / \mathrm{s}$ in $\mathrm{Sn}$ at $25^{\circ} \mathrm{C}$ ) but solubilities small.

Reasonable diffusion coefficients at elevated temps $\left(\sim 100^{\circ} \mathrm{C}\right)$. Range of stoichiometry limited.

Rapid diffusion at ambient temperatures and satisfactory range of composition.

$\mathrm{Al}: \tilde{D}_{\mathrm{Li}}=3 \times 10^{-12} \mathrm{~cm}^{2} / \mathrm{s}\left(300^{\circ} \mathrm{C}\right)$

Si : $\tilde{D}_{\mathrm{Li}}=1 \times 10^{-7} \mathrm{~cm}^{2} / \mathrm{s}\left(500^{\circ} \mathrm{C}\right)$

InSb : $\widetilde{D}_{\mathrm{Li}}=5 \times 10^{-7} \mathrm{~cm}^{2} / \mathrm{s}\left(200^{\circ} \mathrm{C}\right)$

Range of solubility limited.

Rapid diffusion at ambient temperatures. Solid solution behaviour reversible at low concentrations of $\mathrm{Li}$. At higher concentrations irreversible changes produced during incorporation of $\mathrm{Li}$.

Compounds having layer or fibrous structure with Van der Waals bonding to permit rapid incorporation of lithium. The asterisk denotes only partial reversibility. Diffusion rate of lithium strongly influenced by $\mathrm{Ti} / \mathrm{S}$ ratio in $\mathrm{TiS}_{2}$.
\end{abstract}

$\mathrm{KCl}$ eutectic), and it will be difficult to find a superior material. A liquid electrolyte must be used with $\mathrm{TiS}_{2}$ because of the relatively large volume changes $(9 \%$ change in the lattice parameter) which accompany the incorporation of $1 \mathrm{~g}$ atom of lithium [12]. It would be impossible to use a solid electrolyte as the integrity if the solid electrolyte-solid electrode interfacial contact cannot be maintained because of the large volume changes associated with the electrode. It is appropriate therefore to examine the properties of alternative solid solution electrodes which might be expected to exhibit relatively small volumes changes due to the incorporation of an electroactive species such as lithium.

This type of S.S.E. material would probably require to possess a framework structure with the mobile 
electroactive species located in channels (preferably three dimensional) in contrast to the layer structures adopted by the transition chalcogenides such as $\mathrm{TiS}_{2}$. Investigations on selected framework solid solution electrodes are reported in subsequent sections.

4. Recent measurements on selected solution electrodes. - 4.1 $\mathrm{Li}_{x} \mathrm{VO}_{2}$. - The rapid diffusion of lithium in $\mathrm{TiO}_{2}$ was reported [13] in 1964 and the anisotropic nature of the mass transport behaviour was attributed to the channels parallelled to the $C$ direction in the rutile structure. In contrast to $\mathrm{TiO}_{2}$, the compound $\mathrm{VO}_{2}$ is a good electronic conductor [14] above $70^{\circ} \mathrm{C}$ and at ambient temperatures when the $\mathrm{O}-\mathrm{Ti}$ is smaller than 1.95. Appropriate polycrystalline and single crystal samples were prepared and the thermodynamic data are summarized in figure 5.

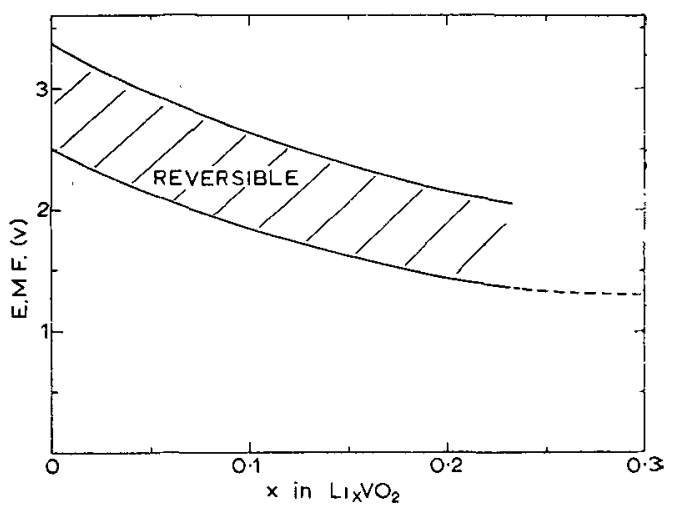

FIG. 5. - Equilibrium emf versus composition for $\mathrm{Li}_{x} \mathrm{VO}_{2}$.

The measurements were made with three electrode cells using propylene carbonate containing $\mathrm{LiClO}_{4}$ as the electrolyte as described [4] for the experiments on $\mathrm{Na}_{x} \mathrm{TiS}_{2}$. The reproducibility of the data was relatively poor and this spread of results was subsequently attributed to the presence of crystallographic shear planes in the samples. The density of shear planes was examined by high resolution electron microscopy using lattice imagining technique and those samples with the highest density of shear planes exhibited the smallest lithium solubility. The lithium chemical diffusion coefficient varied from approximated $5 \times 10^{-7} \mathrm{~cm}^{2} / \mathrm{s}$ at low concentrations to $10^{-10} \mathrm{~cm}^{2} / \mathrm{s}$ near the limit of solubility. Clearly the presence of shear planes was impeding the mass transport of lithium as the one-dimensional channels become blocked by the presence of displaced vanadium ions. This observation confirms the limited applicability [15] of one-dimensional channel structures for fast ion conducting materials, and also emphasizes the influence of non-stoichiometry on the mass transport properties.

$4.2 \mathrm{Cu}_{x} \mathrm{FeS}_{4}$ (BORNITE). - The structure of bornite can be regarded as being derived from the chalcopyrite $\left(\mathrm{Cu}_{2} \mathrm{FeS}_{4}\right)$ or anti-fluorite type [16] and excess copper. can be accommodated within three-dimensional interconnecting channels to produce the formula $\mathrm{Cu}_{5} \mathrm{FeS}_{4}$. The thermodynamics and transport properties have been measured using cells of the type :

$$
\mathrm{Cu} / \mathrm{CuSO}_{4}(\mathrm{aq}) / \mathrm{Cu}_{5-x} \mathrm{FeS}_{4} \text {, }
$$

and the results are summarized in figure 6. Attention is drawn to the high values copper diffusion coefficients at ambient temperatures and to the fact that not more than 1.5 copper atoms can be reversibly removed from the structure. When the copper content is reduced below $\mathrm{Cu}_{3.5} \mathrm{FeS}_{4}$ there is a marked contraction (see Fig. 7) in the lattice parameters (approximately $5 \%$ ) and copper cannot be titrated back into the material. Prior to this composition the change in lattice parameters is small $(1 \%)$ and satisfactory interfaces can be fabricated with copper conducting solid electrolytes (e.g. $\mathrm{CuAl}_{11} \mathrm{O}_{17}$, and $\mathrm{Cu}_{7} \mathrm{C}_{6} \mathrm{H}_{14} \mathrm{~N}_{2} \mathrm{Br}_{8}$ ) to allow investigations into the transfer of ions across solid electrolyte-electrode interfaces.

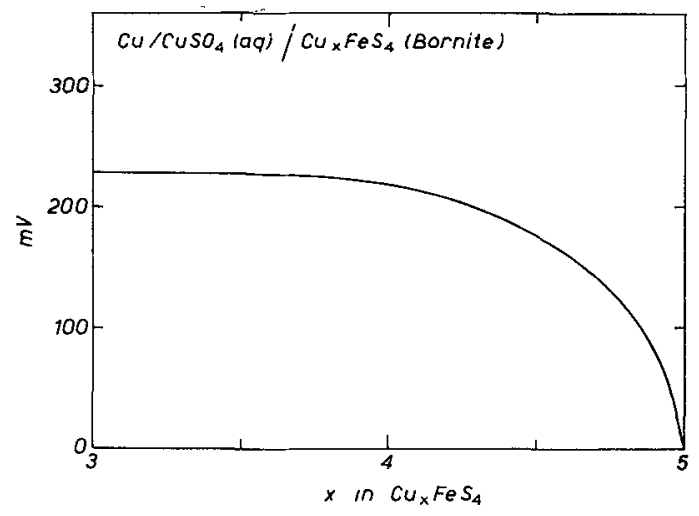

FIG. 6. - Equilibrium emf yersus composition for $\mathrm{Cu}_{x} \mathrm{FeS}_{4}$.

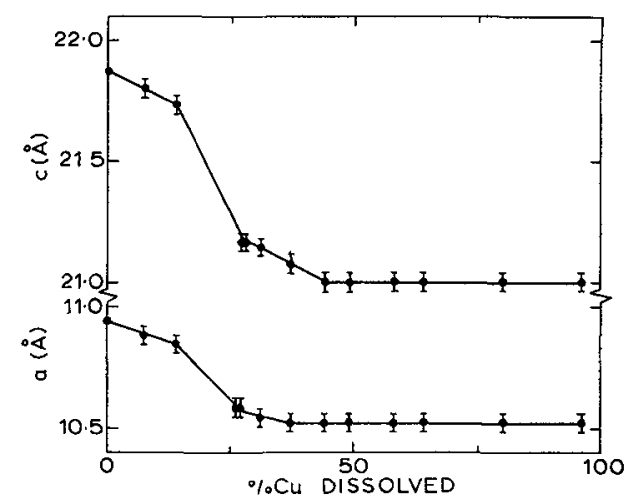

FIG. 7. - Variation in lattice parameter with composition for $\mathrm{Cu}_{11} \mathrm{FeS}_{4}$.

$4.3 \mathrm{~K}_{1+x} \mathrm{Fe}_{11} \mathrm{O}_{17}$ - - Alkali ferrites combine the high ionic conductivity of beta alumina with a moderate electronic conductivity and a wide range of stoichiometry. These compounds can therefore serve 
as model systems for investigations into solid solution electrodes, and at the same time can provide information about the variation of ionic conductivity with concentration of charge carriers which will be relevant to discussions about the mechanism of conduction in the structurally related sodium beta-alumina. Using the experimental arrangement depicted in figure 8 which incorporates both ionic and electronic blocking electrodes, together with ionic and electronic voltage probes, it has been possible to measure [17] the partial molar thermodynamic quantities and the partial ionic and electronic conductivities as a function of potassium content. The composition was adjusted by a series of coulometric titrations and the equilibrium emf-composition curve is reproduced in figure 9. A feature of this curve is the rapid rise in cell emf around the $x$ value of 0.09 in $\mathrm{K}_{1+{ }_{x}} \mathrm{Fe}_{11} \mathrm{O}_{17}$ which

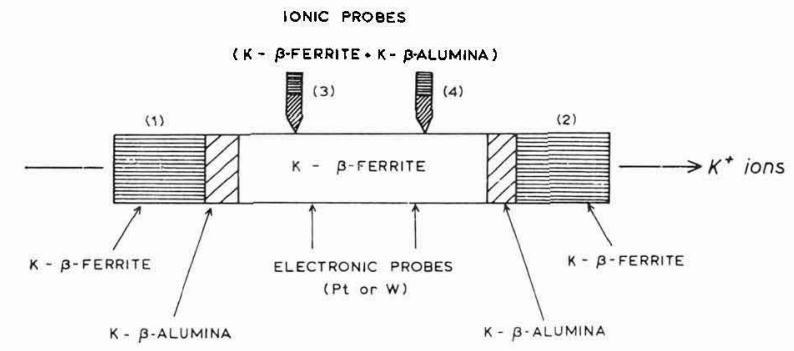

FIG. 8. - Experimental arrangements for measuring transport properties of $\mathrm{K}_{1+x} \mathrm{Fe}_{11} \mathrm{O}_{17}$.

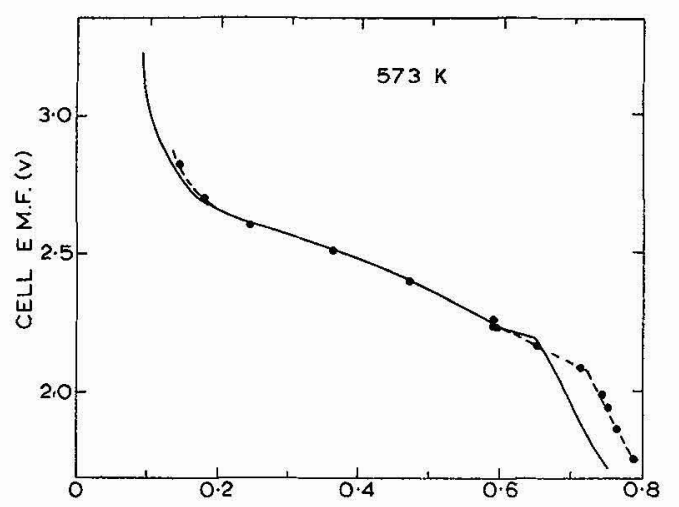

FIG. 9. - Equilibrium emf versus composition for $\mathrm{K}_{1+x} \mathrm{Fe}_{11} \mathrm{O}_{17}$.

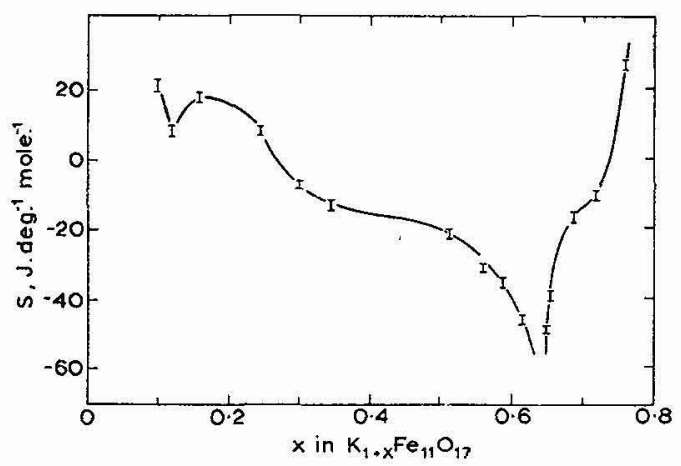

FrG. 10. - Partial molar entropy of solution of potassium in $\mathrm{K}_{1+x} \mathrm{Fe}_{11} \mathrm{O}_{17}$ as a function of composition. suggests that the structure is stabilized by the presence of excess potassium in the conduction plane. By measuring the cell emf as a function of temperature the partial molar enthalpy and entropy can be obtained and values for the entropy are shown in figure 10 . The deep minimum in the entropy values around $x=0.7$ suggests that the distribution of potassium ions becomes ordered around this composition.

Utilizing both steady-state and transient D.C. measurements has enabled both the partial ionic and electronic conductivity to be obtained [17]. The variation in partial ionic conductivity with composition exhibits a parabolic relationship as depicted in figure 11. If it is assumed that the excess potassium ions are responsible for the ionic conduction then the model of Wang, Gaffari, and Choi [18] predicts a parabolic type dependence of conductivity upon composition as observed in the present work, although it should be emphasized that this relatively simple electrostatic model does not take into consideration additional complicating factors such as the presence of extra interstitial oxygen ions in the conduction plane.

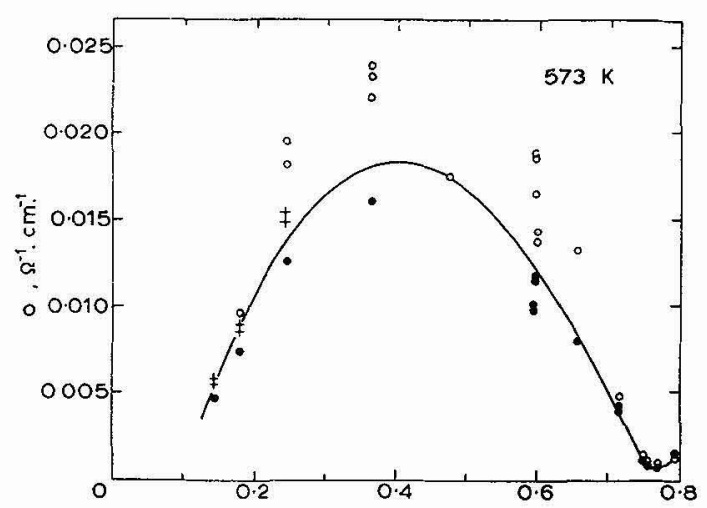

FIG. 11. - Partial ionic conductivity as a function of potassium content.

Analysis of the transient voltages is consistent with the theory developed by Yokata [19] in which the transient voltages are controlled by the chemical diffusion coefficient $(\tilde{D})$ and typical values are shown in figure 12.

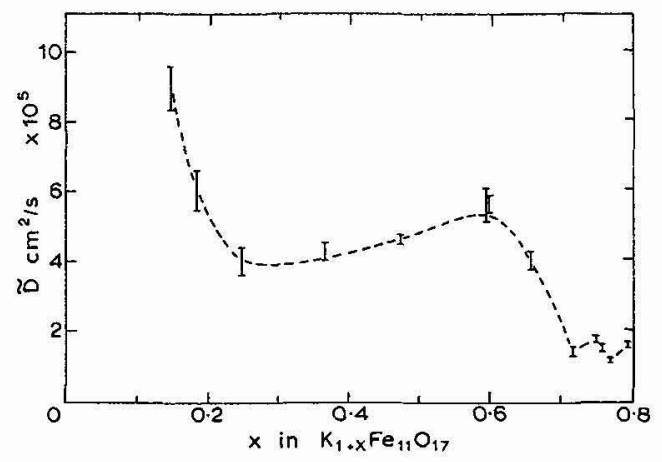

FIG. 12. - Chemical diffusion as a function of potassium content. 
5. Interfacial properties. - The transfer of the electroactive species across electrolytesolid solution electrode interfaces has so far received little attention. Preliminary investigations [19] involving the electrolyte $\mathrm{CuBr} / \mathbf{N}_{1} \mathbf{N}^{1}$ dimethyl-tri-ethylene-diomine-dibromide clearly indicates that copper transport across the interface can be much more rapid in the absence of electro-crystallization of new phases. It is well known that the electrode kinetics for the transfer of protons at the palladium/aqueous electrolyte interface can be rate-limiting unless special precautions are taken to activate the metal surface, and that the anodic reaction involving the removal of hydrogen from the palladium is slower than the reverse cathodic process. Transfer of lithium from molten salts into titanium disulphide is very rapid whereas the transfer of alkali metals into the same S.S.E. from organic solvent electrolytes can be influenced by the type of solute employed. Good interfacial contacts can be prepared between mechanically soft materials such as $\mathrm{Ag}_{2} \mathrm{~S} / \mathrm{AgI}$ which can be readily plastically deformed. It is much more difficult to ensure good interfacial contact between two hard ceramic materials such as $\mathrm{K}$-beta-ferrite. In principle it should be possible to fabricate satisfactory interfaces by hot pressing techniques. However for these particular materials the situation is complicated due to a large difference in thermal expansion between K-beta alumina $\left(7 \times 10^{-6}\right)$ and K-beta-ferrite $\left(13 \times 10^{-6}\right)$ which produces cracks at the interface on cooling.

The problems associated with maintaining a good solid electrolyte/solid electrode interface have already been mentioned in section 3. The incorporation of the electroactive species within the solid solution elec-

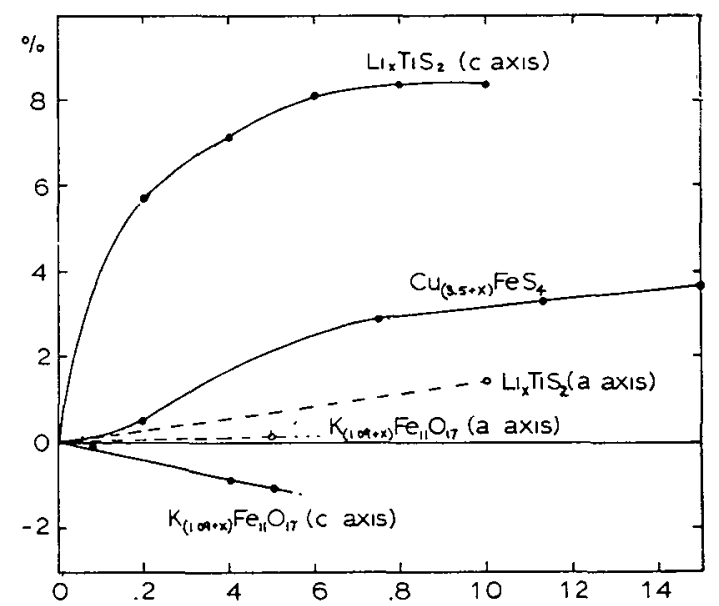

FIG. 13. - Lattice parameter as function of mobile on concentration.

trode invariably produces a charge in the unit cell dimensions. If this volume change is excessive then the integrity of the solid interface will be destroyed. It is of interest therefore to compare changes in unit cell parameters and relevent data is summarized in figure 13 for the selected solid solution electrodes, $\mathrm{Li}_{x} \mathrm{TiS}_{2}, \mathrm{Cu}_{3.5+x} \mathrm{FeS}_{4}$ and $\mathrm{K}_{1.09+x} \mathrm{Fe}_{11} \mathrm{O}_{17 .}$. The changes in volume associated with the framework structures are much smaller than those associated with $\mathrm{Li}_{x} \mathrm{TiS}_{2}$ electrodes which consist of $\mathrm{TiS}_{2}$ slabs weakly bonded by Van der Waals forces. It is probable therefore that useful solid electrolyte/solid electrode will be fabricated using appropriate framework solid solution electrodes.

\section{References}

[1] STEELE, B. C. H., Fast Ion Transport in Solids, Ed. W. Van. Gool (North Holland, Amsterdam), 1973, p. 103.

[2] Steele, B. C. H., Superionic Conductors, Ed. G. D. Mahan and W. L. Roth (Plenum, New York), 1976, p. 47.

[3] Murphy, D. W. and Trumbore, F. A., Metal Chalcogenides as Reversible Electrodes in Non-Aqueous Lithium Cells, To be published in J. Cryst. Growth.

[4] Winn, D. A., Shemilt, J. M. and Steele, B. C. H., Mater. Res. Bull. 11 (1976) 559.

[5] AtLas, L. M., The Chemistry of Extended Defects in NonMetallic Solids (North Holland, Amsterdam), 1970, p. 425.

[6] Dorken, L. S. and Gurry, R. W., Physical Chemistry of Metals (McGraw Hill, New York), 1953 p. 87.

[7] Steele, B. C. H., Critical Materials Problems in Energy Production Ed. C. Stein (Academic, New York), 1976 p. 711.

[8] Whitringham, M. S., J. Electrochem. Soc. 123 (1976) 315.

[9] Whittingham, M. S., Science 192 (1976) 1126.
[10] Gaines, L. H., Francis, R. W., Newman, G. H. and RaO, B. M. L., 11th I.E.C.E.C., Lake Tahoe, Sept. 1976.

[11] Inman, D. and MariKer, Y. E. M., Abs. 2, Symp. on Novel Electrode Materials, Brighton, U. K. Sept. 25/26th, 1975.

[12] Whittingham, M. S. and Gamble, F. R., Mater. Res. Bull. 10 (1975) 363.

[13] Johnson, O. W., Phys. Rev. 136 (1967) A 284.

[14] Nagasawa, K. et al., J. Cryst. Growth, 17 (1972) 143.

[15] Steele, B. C. H., Mass Transport Phenomena in Ceramics, Ed. A. R. Cooper and A. H. Heuer (Plenum, New York) 1975 , p. 269.

[16] Koto, K. and Morimoto, N., Acta Cryst. B 31 (1975) 2268.

[17] Dudley, G. J. and Steele, B. C. H., J. Solid State Chem., 21 (1977) 1 .

[18] Wang, J. C., Gaffari, M. and Chol, S., J. Chem. Phys. 63 (1975) 772.

[19] LAZZARI, M., et al., J. Power Sources 1 (1976) 57. 